\title{
Amor contra interés, hijos contra padres: Las Bodas de Camacho en el siglo XVIII
}

\author{
Ceferino Caro*
}

El objeto de este análisis es presentar cuatro versiones del episodio de las Bodas de Camacho aparecidas entre 1772 y 1784, para intentar poner en luz, por una parte, cómo los distintos autores elaboraron el material original para amoldarlo a los gustos del período y, por otra, en qué medida las nuevas piezas representaban un mensaje coherente con el de Cervantes o por el contrario introducían una novedosa aportación a un tema social de actualidad usando un episodio de la novela. Cabe sospechar que así fuera porque en el siglo XVIII el aparatoso suicidio de Basilio no engañaba ya a nadie, y tampoco podía ser sorpresa para los espectadores el golpe de escena final y el triunfo de los amantes aparentemente derrotados ${ }^{1}$. Además el episodio aquí narrado tampoco era el más popular de los de la novela, como se puede comprobar de la divulgación realizada por Santos $\mathrm{Alonso}^{2}$, y sin embargo Las Bodas de Ca-

* Madrid.

1. Cervantes, Don Quijote, ed. F. Sevilla Arroyo, Madrid, Alianza, 2002, II, capítulos XIX-XXI. Se citará siempre esta edición. Para una exposición de la práctica y la teoría teatral en España en la segunda mitad del siglo XVIII, ANDIOC, René, Teatro y sociedad en el Madrid del siglo XVIII, Madrid, Castalia, 1976; CARnERo, Guillermo, Estudios sobre el teatro español del siglo XVIII, Zaragoza, Prensas Universitarias, 1997; CASO GonZÁlez, Jose Miguel, "La literatura de 1759 a 1808", Historia de España dir. J. M. Jover, tomo XXXI, Madrid, Espasa Calpe, 1987; PALACios Fernández, Emilio, "Teatro", Historia literaria de España en el siglo XVIII, ed. F. Aguilar Piñal, Madrid, Trotta, 1996; ID. Teatro popular español del siglo XVIII, Lleida, Milenio, 1998.

2. Santos Alonso, Hilario, Tertulia / de la Aldea, / y miscelánea curiosa de sucesos / notables, Aventuras divertidas, y Chistes gra- / ciosos, para entretenerse las noches del / Invierno, y del Verano. / Su Autor / Don Hilario Santos Alonso, / residente en esta Corte. / Con licencia. / Madrid: en la Imprenta de D. Manuel Martín, calle de la / Cruz, donde se hallará ésta, y otras diferentes. Año de 1768. Más ediciones de Madrid, Manuel Martín, 1775 -1776 y Joseph Manuel Martín, 1782. 
macho, frustradas para uno, logradas para otro, gozaron de cierto favor en un momento dado del Setecientos.

Las obras aquí citadas muestran una indudable intertextualidad, por lo que se puede afirmar que en medida diversa todas participan de una misma sensibilidad, de una voluntad de escenificar un mensaje de importancia social hacia finales del siglo XVIII, desde un planteamiento teatral cuya forma no traiciona la narración novelesca, sino que es impuesta por el metamensaje. Es decir, que hay una relación dinámica entre motivación dramática y metamensaje de las Bodas; como ha dicho Polt "El peso de la[s] obra[s] descansa, pues, no en el desenlace sino en cómo se llega a él". Pero no porque los espectadores del Dieciocho no pudieran sorprenderse de la treta de Basilio, sino porque lo que realmente importaba ciento cincuenta años después del Quijote era precisamente ver que el amor de los dos jóvenes triunfaba, con toda la carga de novedad y de crítica sobreentendida. Para justificar este planteamiento convendrá examinar someramente, primero, los cuatro textos.

Son, siguiendo las fechas de sus versiones, la manuscrita Las bodas de Camacho. Zarzuela en dos actos, llamada en otra redacción Comedia nueva jocoseria, en dos actos, Las Bodas de Camacho, de $1772^{3}$. En 1784 veían la luz Las bodas de Camacho el rico de Meléndez Valdés ${ }^{4}$ y El amor hace milagros

3. Las bodas de Camacho. Zarzuela en dos actos. Anotación en la parte superior del título: “1772”. Primer folio: Las Bodas de Camacho./ Zarzuela nueva Española / Personas que hablan en ella / [...] De d. Leandro Ortala y Maqueda. Biblioteca Nacional (en adelante, BNM) mss 14608(1). La misma Comedia nueva joco-seria, en dos actos. Las Bodas de Camacho. Comentario en el mss: "Bodas (Las) de Camacho (en 2 actos) / distinta de la de Melendez / Vallads". BNM mss 15918. Según Gough LaGrone, Gregory, The imitation of "Don Quixote” in the Spanish drama, Philadelphia, University of Pennsylvania Press, 1937, pp. 50-52 y estando a ese apunte, el autor sería Antonio Valladares y Sotomayor y el manuscritto autógrafo. HERRERA NAVARRo, Jerónimo,Catálogo de autores teatrales del siglo XVIII, Madrid, FUE, 1993, no atribuye a Valladares el pseudónimo de Ortala y Maqueda pero menciona una obra suya "Bodas de Camacho, comedia joco-seria en dos actos y verso. Ms. Biblioteca Nacional". Sí reconoce esa autoría SEBOLD, Russell P. Contra los mitos antineoclásicos españoles, en www.cervantesvirtual.com. De los dos textos el ms. 14608(1) comprende también la censura del P. D. Juan de Aravaca y del Vicario eclesiástico. Parecer positivo di Ignacio López de Ayala en 1 de Febrero de 1772 y licencia concedida por el Consejo de Castilla dos días más tarde, aunque no hay prueba de que se imprimiera. Las dos versiones son muy parecidas; la Comedia joco-seria es un texto no corregido pero con ortografía mejor y le falta un folio que corresponde a la parte final de la escena 2 del primer acto. No indica la división en escenas. La Zarzuela conserva algunos versos tachados y sustituidos por otros entre los renglones originales, mientras que la Comedia joco-seria no presenta correcciones y mantiene los versos enmendados en la otra; por lo tanto la Zarzuela debe considerarse la versión definitiva y es la que aquí se citará.

4. MelÉndez Valdés, Juan, Las bodas de Camacho el rico. Comedia pastoral premiada por la Villa de Madrid, para representar en el teatro de la Cruz, con motivo de los festejos públicos que ejecuta por el feliz nacimiento de los serenísimos infantes Carlos y Felipe y ajuste definitivo de la paz. Su autor el dr. d. Juan Meléndez, Valdés, Madrid, Ibarra, 1784. Editada por Palacios Fernández, MELÉNDEZ VALDÉs, Juan Obras completas, III, Madrid, 1997, pp. 3-102. Otra edición moderna: MELÉNDEZ VAldÉs, Juan, Obras en verso, ed. Polt-Demerson, Oviedo, 1983, II, pp. 1089-1178. Para PalACIOS FERnÁNDEZ, "Teatro" cit. p. 214, era una "fábula pastoril convencional”. Astorgano AbAJo, Antonio, Biografía de D. Juan Meléndez. Valdés, Badajoz, Diputación Provincial, 1996, la llama "comedia pastoril" p. 96. Molina NAVARro, Gabriel, Catálogo de una colección de libros cervantinos, Madrid, Librería de Bibliófilos Españoles, 1916, n. 929; Gough LaGrone, op. cit.; Aguilar PiÑal, Francisco, "Cervantes en el siglo XVIII", Anales Cervantinos, 1983, pp. 153-163. Un comentario al texto 
de Gómez Labrador 5 . En último lugar hay una Comedia Pastoral en cinco actos, Las Bodas de Camacho ${ }^{6}$ también manuscrita y de la que sólo se sabe que "no es ésta la obra de D. Juan Meléndez Valdés, de igual título, impresa y representada en Madrid en 1784" como indica un comentario del manuscrito. La Comedia Pastoral debe mucho al texto de Meléndez y también es más prolija y declamatoria; copia prácticamente la presentación de los personajes y la ambientación escénica rozando casi el plagio.

El desarrollo del asunto es lineal y tiene dos fases bien definidas. Empieza con la Zarzuela, en la que Valladares introdujo el tema de las Bodas de Camacho en el teatro dieciochesco y por ser la primera elaboración y a causa de su género especial presenta unos rasgos que no se mantendrían en las obras siguientes. Todas seguirían, en distinta medida, la ambientación idílica. En la Zarzuela "La acción se representa en un Valle inmediato del Lugar de Camacho". El acto primero empieza con una

Vista hermosa de un dilatado valle en el que se descubren algunas tiendas de campaña y arcos cubiertos de hojas y flores con adornos correspondientes a la celebración de unas bodas aldeanas. A un lado se verán varios labradores y labradoras ocupados en las disposiciones del banquete, para el cual habrá gran copia de prevenciones, especialmente de caza y aves colgadas entre los árboles. A otro se oirán instrumentos rústicos y saldrán contando y bailando una tropa de los mismos con alegría y algazara. A lo lejos se deja ver el lugar.

En las siguientes redacciones la ambientación se torna menos prolija; la Comedia Pastoral se limita a indicar que "La escena representará una enra-

en Polt, John H. R. "Invitación a 'Las bodas de camacho"”, Coloquio internacional sobre teatro español del siglo XVIII, Abano Terme, Piovan, 1988, pp. 315-331. Dice: "Según dos cartas que Meléndez le escribió a su amigo Jovellanos en 1777, la génesis de Las bodas se remonta a ese año". Las Bodas de Camacho fueron del gusto de los ilustrados españoles, como se puede notar por el juicio de Sempere: "En esta parte es innegable que el Señor Meléndez tuvo mucho más que hacer, que el Taso en su Aminta, la cual no se escribió para representarse en ningún teatro. Y el estilo tampoco creo que le llevará muchas ventajas, al Italiano, como no sea la de haber escrito primero". SEMPERE Y GUARINOS, Juan, Ensayo de una biblioteca de los mejores escritores del reinado de Carlos III, Madrid, 1789, IV, pp. 53 ss.

5. Gómez Labrador, Pedro Benito,, El amor hace milagros. Comedia nueva tomada del Capítulo veinte del Libro II de la Historia de Don Quijote de la Mancha por el Bachiller don Pedro Benito Gómez Labrador, Profesor de Derecho en esta Universidad de Salamanca y Presidente de su Real Academia de Leyes, Salamanca, Vda. de Nicolás Villagordo, 1784. Gough LAGrone, op. cit.; AguiLAR PIÑAL, "Cervantes..." cit. Presentación somera de la comedia en HuARTE, Antonio, "Detalles de la vida universitaria de Gómez Labrador”, La Basílica Teresiana, 62, 1919, pp. 249-250.

6. Las Bodas de Camacho, comedia pastoral en cinco actos, BNM mss 14071(9). El ms. lleva la nota: "Es obra de D. Juan Meléndez Valdés, representada en Madrid en 1784" tachada y a continuación otro apunte "Luego he visto que ésta no es la obra de Meléndez y que no hallo noticia de dónde ni cuándo ha sido representada. Lo único que parece claro, es que esta obra fue escrita hacia fines del siglo XVIII o principios del XIX”. Gough LaGrone, op. cit.; PAZ y Meliá, Antonio, Catálogo de las piezas de teatro que se conservan en el departamento de manuscritos de la Biblioteca Nacional, Madrid, Patronato Biblioteca Nacional, 1934. 
mada como la que describe Cervantes en el Cap. ${ }^{\circ} 20$ de la 2.. parte de su Historia" y Meléndez remite sencillamente a los capítulos del Quijote de los que ha sacado la inspiración, pero añade que "La música es de Don Pablo Esteve, Compositor del Teatro de la Cruz y las Decoraciones del Pintor Don Antonio Carnicero". La línea austera no se encuentra en Gómez Labrador, de quien ya se sabe que lo tentaba la vena lírica, y por eso aprovechaba algunas ocasiones que le ofrecía la novela para amplificar, con ecos dieciochescos, el ambiente pastoral de la acción. En el primer acto las palabras de Basilio:

Ya se ausenta Diana y viene el día,
ya la lucida Aurora va volviendo
a las marchitas flores su alegría,
y las líquidas perlas sacudiendo,
que el prado en sus cabellos sostenía,
así el placer va en todo difundiendo,
que a la porfía está cada elemento
dando evidentes muestras de contento...

amplifican lo escrito por Cervantes en II, XX: “Apenas la blanca aurora había dado lugar a que el luciente Febo, con el ardor de sus calientes rayos, las líquidas perlas de sus cabellos de oro enjugase...".

Debido al carácter popular de estas obras teatrales ${ }^{7}$, al género al que se adscribe la Zarzuela y al deseo de montar un espectáculo vistoso, los autores de las comedias también recurrieron a danzas y coros en sus obras. Cervantes había narrado en el capítulo XX de Don Quijote el baile alegórico de las bodas aunque sin demasiados detalles, a la vez que mencionaba tres danzas, una tras otra, de las que las comedias dieciochescas han conservado la última, "de artificio y de las que llaman habladas" con los dos bandos de ninfas seguidoras de Cupido las unas y del Interés las otras. Así se presentan en El amor hace milagros y en la Comedia Pastoral: "Danza de 8 Pastores y Zagalas, que traerán sus nombres en tarjetas; y en cantando con el Baile la 1. ${ }^{a}$ Copla se dividirán en 2 Coros a los bastidores. Del uno vendrá por guía el Amor con sus insignias; del otro el Interés con las suyas". Éstas eran respectivamente "Poesía, Discreción, Buen Linaje, Valentía” y "Liberalidad, Dádiva, Tesoro, Posesión”. Para demostrar la libertad de elaboración, los autores de los dos textos colocan esta danza al principio de la representación y no en el momento en que tiene lugar en la novela. Meléndez Valdés recurre también a los coros de muchachas y muchachos para ofrecer canciones líricas (pp. 25-26) que no se encuentran en Cervantes y que crean un ambiente radicalmente distinto de la alegoría moralizante original:

7. Siguiendo a Palacios Fernández, Teatro popular... cit. La variedad de posibles interpretaciones del género de estas comedias justificaría de por sí su estudio. 
El coro irá pasando y dividiéndose en dos bandas.

$\begin{array}{ll}\text { Coro I. } & \text { Tras el divino fuego } \\ & \text { de su adorada esposa } \\ & \text { Camacho vuela ciego } \\ & \text { cual tierna mariposa. } \\ \text { Coro II. } & \text { Quiteria desdeñosa } \\ & \text { su ardor cubrir procura, } \\ & \text { cual virgen vergonzosa, } \\ & \text { cual niña mal segura. } \\ \text { Los dos coros. } & \text { Pues baste de extrañezas, } \\ & \text { y en tálamo de flores } \\ \text { Coro I. } & \text { goce ya sus finezas, } \\ \text { Coro II. } & \text { temple ya sus ardores. } \\ \text { Los dos coros. } & \text { En tálamo de flores } \\ & \text { goce ya sus finezas, } \\ & \text { temple ya sus ardores. }\end{array}$

La última adaptación del episodio cervantino es la Comedia Pastoral Bodas de Camacho, también muy parecida a los textos de Meléndez Valdés y Gómez Labrador ${ }^{8}$. Esta comedia es seguramente posterior a todas las demás porque recoge puntos y planteamientos que estaban en la Zarzuela, en Meléndez y también en Gómez Labrador, como por ejemplo el arranque de la acción con danzas de zagalas y zagales pero se toma la libertad de ambientar la primera escena de manera distinta: "Se descubre en el fondo de la enramada un Castillo, con este letrero en la parte superior [...] Buen Recato" es decir, el mismo material cervantino pero en sucesión temporal dislocada.

Como es el primer tentativo de aproximación, en la doble versión de la Zarzuela la figura de Don Quijote tiene una centralidad mayor que en las comedias sucesivas. Gough LaGrone ya reconoció que el material novelesco "se alteró sin escrúpulos" y que caballero y escudero "se olvidan de sus modelos cada vez que se presenta la oportunidad de hacer reír tal y como son"9. Por ejemplo, cuando Don Quijote se entera de las dificultades de los amantes se encoleriza y al verlo la reacción de los villanos es interesada, intentando aplacar su ira porque temen que les estropee la ceremonia; para negar ese punto de vista tierra a tierra el caballero ridículamente cree que se las ha de ver con larvas y encantamientos obra de algún mago su enemigo.

Aquí la Zarzuela mantiene una visión del caballero muy anclada aún en la tradición de la figura risible de Don Quijote, que las siguientes comedias no seguirían, afortunadamente, si se considera un intervalo más grotesco que humorístico, justificado por la naturaleza de la pieza, en el que Antona pide a Don Quijote amparo para obligar a Perico a casarse con ella. Las dos versiones de la Zarzuela presentan diferencias en este episodio: el primer acto de la Zarzuela acaba de manera más sobria con Antona diciendo

8. Pocas diferencias de detalle, "imitación más servil del original" Gough LaGrone, op. cit., pp. 56-57.

9. Gough LaGrone, op. cit., pp. 50-52. 


$\begin{array}{ll} & \text { Obedeceros espero, } \\ & \text { pero mirad, que primero } \\ & \text { nos habemos de casar. } \\ \text { D.Q. } & \text { Pues de ese modo. } \\ \text { Antona } & \text { Pues de esa suerte. } \\ \text { Todos } & \text { Todo en contento } \\ & \text { se trocará. } \\ & \text { Viva la andante } \\ & \text { caballería } \\ & \text { que en este día } \\ & \text { sabe triunfar }{ }^{10} .\end{array}$

En cambio la Comedia joco-seria desarrolla la escena hasta límites comprensiblemente omitidos en la versión corregida. Sancho se encarga de oficiar la boda de los dos villanos, porque conocía la ceremonia

y aun suficiencia me sobra, pues me acompaña la misma potestad aquí, que en Roma.

D.Q. Pues cásalos.

Perico Yo protesto en toda forma que soy forzado.

D.Q. Follón, calla, ¿o te envío por Posta al Infierno?

Perico ¿Pues acaso, si me caso con Antona, no voy a él?

Antona No Señor, que va derecho a la gloria.

Sancho Pues de Cura he de servir, cantando fago esta Boda. (Canta) Venga esta mano mi buen Perico, no seas borrico, y tu persona reciba Antona por mujer ya. Así enlazados, muy apretados, a mis preguntas responderán. ¿Quiere Usted al Sr. Perico por su marido?

Antona Sí tal.

Sancho ¿Y usted quiere a la $S{ }^{a}$ Antona por su mujer?

10. En todos los textos citados se ha actualizado la grafía y la puntuación. 


\section{Perico Violentado la querré. \\ Sancho Pues ya está hecho un matrimonio que ni el demonio le podía hacer.}

El disparate se lleva hasta el punto de que D. Quijote remata la faena de su escudero dando la bendición a la recién casada pareja. Siguiendo con la comicidad de brocha gorda el segundo acto empieza con los planes de los villanos para encerrar a Don Quijote "Caverna abajo en un cepo" para que no molestara.

En El amor hace milagros Gómez Labrador presenta a Don Quijote y Sancho como personajes marginales, al escudero para hacer el típico papel de gracioso de la comedia áurea, aunque aquí Sancho encuentra un compañero inesperado: el mismísimo Ginesillo de Pasamonte es, por gracia de Gómez Labrador, criado de Basilio. De este solo apunte se puede intuir que la intención principal de esta comedia es la parodia, con referencias jocosas a las convenciones teatrales y menciones de los personajes a la realidad extraliteraria, pero su deuda con Meléndez salta a la vista ${ }^{11}$. Gómez Labrador no recalca la locura del caballero andante y da inicio a su acción cuando Ginesillo el gracioso oye las quejas de su amo y se pregunta cómicamente si no se estaría preparando para subir al púlpito a dar un sermón. Este rasgo se debe entender por lo que vale en la economía de la comedia, esto es rebajar inmediatamente el nivel de dramatismo de los amores pastoriles, como más abajo se verá. Basilio aparece en la escena presa de los furores amorosos declamatorios del barroco desorbitado:

Primero el mar se secara, primero se hundiera el cielo, que yo a Quiteria olvidara (p. 10)

dice, y la réplica del criado coloca esos sentimientos en la realidad:
Tente tente, pobre Sol, pobre cielo, no te caigas, (Aparte.) ¡Ay! Pobre mar, no te seques, por que ya los peces claman. Yo bien quisiera, señor, el que Vmd. reflexionara que no todo lo que luce suele ser oro, ni aun plata.

Es cinismo, crítica de las fórmulas estéticas ya agotadas e intención de conducir las relaciones amorosas a otro plano mucho más cercano a la reali-

11. "Greatly indebted to the play by Meléndez Valdés". Don Quijote y Sancho "appear, as lifeless figures, only in the third act". Gough LAGrone, op. cit., pp. 57-59. 
dad de la experiencia. Siguiendo el planteamiento de la acción desde la primera Zarzuela, se concierta un encuentro de Basilio y Quiteria por obra de Ginesillo, entrando al servicio del padre de la joven y entregando un billete a la muchacha, reproduciendo de paso el episodio de la carta de Don Quijote a Dulcinea y creando paralelismos y guiños de complicidad con el lector enterado de la novela. De hecho dice Basilio:

\author{
La carta tómala y ve, \\ cuando llegues a entregarla, \\ cómo se queda aquel ángel, \\ si grave, o sobresaltada. \\ De todos sus movimientos \\ me has de dar noticia exacta, \\ por que de ello he de sacar \\ lo que ella oculta en el alma (p. 11).
}

Así empieza el segundo acto; Quiteria recibe la carta, la lee, llora y sufre por las quejas de su enamorado. Vuelve a aparecer Basilio igual de desesperado que en el primer acto y vuelve a declamar más versos, que se pueden comparar con los de la penitencia de Don Quijote en Sierra Morena:

El Amor hace milagros, pp. 16-18).

Vos troncos que sois en estos prados perpetuos compañeros de pastores, que en vos suelen dejar significados unos sus llantos, otros sus amores; ya que es uso también que desdeñados dejen en vos escritos sus dolores, donde al tiempo resisten más constantes que en campo de oro letra de diamantes, supuesto que aquí vengo a ser despojo, y entregarme en los brazos de la muerte, que morir de una vez mejor escojo que no vivir muriendo de esta suerte, por conservar mi nombre a vos me acojo, queriéndolo poner en tronco fuerte, que suelen (ya lo dije) desdichados lograr por vos victoria de sus hados. Vosotras, peñas cóncavas, morada de sátiros y faunos amorosos, que repetís la voz acrecentada de los pastores dulces y armoniosos, no olvidéis en la edad más apartada de aumentar mis suspiros dolorosos, porque se verifique que hay belleza que vos excede mucho en la dureza. Desde este día el eco deleitoso de las pequeñas aves, cuyo canto nos avisa que Febo luminoso
Don Quijote, I, 26.

$\quad$ Árboles yerbas y plantas
que en aqueste sitio estáis,
tan altos, verdes y tantas,
si de mi mal no os holgáis,
escuchad mis quejas santas.
$\quad$ Mi dolor no os alborote,
aunque más terrible sea,
pues, por pagaros escote,
aquí lloró don Quijote
ausencias de Dulcinea
del Toboso.
Es aquí el lugar adonde
el amador más leal
de su señora se esconde,
y ha venido a tanto mal
sin saber cómo o por dónde.
Tráele amor al estricote,
que es de muy mala ralea;
y así, hasta henchir un pipote,
aquí lloró don Quijote
ausencias de Dulcinea
del Toboso.
Buscando las aventuras
por entre las duras peñas,
maldiciendo entrañas duras,
que entre riscos y entre breñas
halla el triste desventuras,


viene pisando de la Aurora el manto, sirva al mundo de signo y no dudoso, de que tomando parte en mi quebranto, lo que antes expresaba su contento sirve ya de expresar su sentimiento. Tú, bullicioso arroyo, que en cristales vas a pagar tributo a mayor río, ni cuando abrase el Sol tus arenales, ni cuando estén helados con el frío, permitas que se borren las señales con que queda grabado el nombre mío, $y$ entre tus pardas guijas murmurando vete de mis desdichas lamentando. Vosotras, verdes yerbas de este prado, que entrelazado con las bellas flores en él como de intento se han juntado de la naturaleza los primores, sedme testigos, de que desdeñado sin sentir de la muerte los horrores, siento la crueldad de aquella ingrata que sin darle motivo así me trata.

Muera al fin; mas los troncos de esta sierra sirvan de tristes cirios en mi entierro;

pero ¿espero que habrá quien me dé tierra en este que es lugar de mi destierro?

Sí, que las mismas fieras, que en sí encierra en lóbregas cavernas este cerro,

mi muerte llorarán y su terneza

hará ver, o Quiteria! tu dureza. hirióle amor con su azote, no con su blanda correa; y, en tocándole el cogote, aquí lloró don Quijote ausencias de Dulcinea del Toboso.

\section{O en Don Quijote, I, XXV:}

Éste es el sitio donde el humor de mis ojos acrecentará las aguas deste pequeño arroyo y mis continos y profundos suspiros moverán a la contina las hojas destos montaraces árboles, en testimonio y señal de la pena que mi asendereado corazón padece. ¡Oh vosotros, quienquiera que seáis, rústicos dioses que en este inhabitable lugar tenéis vuestra morada, oíd las quejas deste desdichado amante, a quien una luenga ausencia y unos imaginados celos han traído a lamentarse entre estas asperezas y a quejarse de la dura condición de aquella ingrata y bella, término y fin de toda humana hermosura!

En la Comedia Pastoral el movimiento de la acción se desarrolla en dos planos distintos y no satisfactoriamente trabados; junto a las relaciones amorosas de Basilio, Quiteria, Camacho y Petronila, esto es, la parte central del mensaje, otras escenas se dedican a bosquejar la figura de Don Quijote presentándolo como un pobre mentecato. Camilo solicita a Sancho el relato de la "vida y empleo" de su amo porque estaba muy intrigado y la curiosidad del labrador es indicativa de una mentalidad que aprecia la paz burguesa más que los afanes gloriosos caballerescos: 


\begin{abstract}
¿A qué sin son esas armas,
$y$ andarse por los desiertos

buscando esas aventuras

que él dice?
\end{abstract}

Tras haber escuchado el relato escuderil Camilo medita si podría usar el extraviado caballero a favor de la causa de su amigo.

En cambio desde la Zarzuela hasta la última comedia se mantiene la comicidad agridulce de las reacciones de Sancho ante la riqueza del banquete, con sus lógicas variaciones. La codicia desmesurada ante la abundancia de manjares se presenta sobre todo, como cabía esperarse, en la Zarzuela y en la Comedia Pastoral. En ésta, cuando Camacho pregunta "¿qué hay del almuerzo?" el escudero hace un informe entusiasmado; en la Zarzuela al hablar de las viandas que se estaban preparando para el banquete, Sancho se jacta de haber hecho "cosas prodigiosas":

Comedia Pastoral

... un prado todico lleno de yo no sé qué: de todo, porque alli había rimeros de gallinas, gansos, liebres, de perdices, de conejos; ¡unos montones de panes! ¡Dios los bendiga! ¡Unos

$Y$ más de cuarenta zaques quesos! tendidos por aquel suelo, que consolaba a un cristiano, sólo el mirarlos y olerlos.

Esforcéme cuanto pude, y llegando a un cocinero, que en el vientre de un novillo estaba embaulando, enteros, amén de otras zarandajas, doce lechoncillos tiernos: dijele: hermano, en buena hora tal se la dé Dios le ruego que me dejéis remojar esta sopa en el puchero. Por cierto venís con buenas me respondió con despejo, mirad si halláis por ahí un cucharón y al caldero llegad y un par de gallinas espumadle y buen provecho. Yo no encuentro el cucharón, le dije; y él el caldero en otro desocupando,
Zarzuela

Me arrimé a una grande olla de éstas que sin duda tienen de carne cincuenta arrobas; y a un señor, que la espumaba, pedí me diera una sopa por probar siquiera el caldo, mas él con gran vanagloria, asiendo de una caldera, sacó tres, o cuatro pollas, y me dijo: toma amigo, que hoy no es día en que se acorta la ración con escaseces: que el buen Camacho lo abona, y muy buen provecho os haga: dijo y fuese. Aquí fue Troya pues, embistiendo al caldero, y él a mí, en un cuarto de hora no dejé en él más que huesos. 
se volvió hacia mí diciendo:

a fe que sois delicado,

vaya, tomad, no seáis lerdo,

este ganso y arrimadle

esas gallinas: no tengo

en qué echarlo; pues llevaos

espuma y cuchara a un tiempo

(ff. 31v.-32v.).

En El amor hace milagros Sancho, como era inevitable, se maravilla ante la abundancia de los preparativos de la boda pasando revista a los buenos y varios manjares en una escena que seguramente provocaría la hilaridad del público ante la glotonería del villano hambriento. En Mélendez Valdés -I, 6-, ante la Jauja villanesca la glotonería de Sancho tiene un tono menos exagerado que en las otras comedias:

¡Válame Dios qué día a Sancho viene!

Tiernas pollas... cabritos... y conejos...

pichones... lechoncillos... allá lejos

asándose un novillo... iAy dulces zaques!

¡Aquí también os hallo! ya mis ojos

finos enamorados

no pueden de vosotros apartarse (pp. 30-31).

Por su distinta sensibilidad, Meléndez presenta los preparativos de las bodas de manera más sobria y sobre todo envueltos en una atmósfera de idilio -constantes referencias a la naturaleza y los trabajos del hombre, en las que las viandas son como caza colgada por los robles cual si su fruta fuera, las referencias al trigo en el ejido, a las lumbradas de verano, como para aliviar la crudeza material del cuadro. También es cierto que en Meléndez la demostración de abundancia es más comedida:

Las grandes y abundosas prevenciones

no me es dado contar: veréis tendido

el albo y rico pan así en rimeros,

cual suele el trigo estar en el ejido.

Así veréis arder olmos enteros

cociendo las viandas

cual si fuesen lumbradas de verano.

Así caza colgada por los robles

cual si su fruta fuera.

Ha enramado este valle de manera

que a hurto el Sol ha de entrar, si a vernos viene.

Danzas y bailes de zagalas tiene,

$y$ de zagales juegos y carrera.

Finalmente este día

es todo del placer y la alegría (p. 21). 
Meléndez no ha mantenido el arrobo sanchopancesco ante la riqueza de provisiones sólo por su valor cómico, sino para seguir con la oposición entre la actitud del rústico y la del caballero mientras seguía subrayando la riqueza que ostentaba Camacho.

Hasta aquí lo que el Dieciocho conserva del relato del Seiscientos. Lo novedoso se debe primero a Valladares, quien introduce en la trama personajes inexistentes en la novela: Antona y Perico son dos villanos pensados para añadir comicidad a la acción, pero la aparición de Leandro, padre de Quiteria y sobre todo la de Narcisa, prima suya y enamorada de Camacho, tendrá otra importante función, tan importante que las demás comedias recogerán su presencia porque sin ellas el nuevo sentido que se quería dar a la acción se perdería. La Zarzuela se toma muchas libertades de interpretación de la novela, entre las cuales la que más importa subrayar aquí es que la pintura de los amantes Basilio y Quiteria ha perdido dramatismo para hacerse prosaica: el mozo es "un pobrete" "que tiene muy pocos cuartos" y el padre de ella es "un tacaño Vejete", rasgos que las siguientes obras mantendrían y que marcan un desplazamiento del ambiente pastoril a otro más cercano, en sus contenidos, al drama sentimental ${ }^{12}$. El enamorado pobre y el padre de la chica codicioso hacen un cuadro poco heroico y por el contrario dan a las comedias un sentido de realismo concreto y que responde a la tipología de la acción teatral al uso. En la Zarzuela esta pintura de personajes debía servir para crear caracteres, pero los demás autores la usaron para proporcionar un motor de la acción. En esto los planteamientos son nuevos con relación a Cervantes.

En la interpretación dieciochesca de las Bodas de Camacho la intriga arranca cuando aparece Narcisa, enamorada de Camacho, revelando al público que Basilio no había muerto sino que vagaba por el bosque enloquecido de amor y despecho. Camacho lo encuentra y los dos hombres-Zarzuela, I, 6primero discuten y después pelean con espada y puñal; la reyerta acaba con la intervención de Leandro. En estos lances se nota todavía el peso de la tradición de las comedias del Siglo de Oro, desechada en las demás comedias al desplazar el tono hacia valores más burgueses. Igualmente interesante es la confesión de Narcisa que estaba contenta porque gracias a los disparates del caballero podía "pescar a río revuelto" en sus amores con Camacho valiéndose de la locura de Don Quijote, que en el teatro se convierte en instrumento de las maquinaciones de los amantes y los amigos de los amantes, y no sólo en la Zarzuela. Otra novedad es que Camacho en otros tiempos había dado promesa de matrimonio a Narcisa y la invención sirve para dotar a la acción de un personaje interesado en impedir que las bodas tuvieran lugar y pudiera hacer de cómplice para las intrigas de Quiteria y Basilio. A partir de este momento la acción teatral recupera los derroteros de la novela y precisamente cuando Quiteria iba a dar la mano a Camacho, irrumpe Basilio y los hechos siguen el hilo bien sabido. Mas el padre de Quiteria, Leandro, invalida el ma- 
trimonio y blande el puñal contra su hija; pelean Camacho y Basilio hasta que D. Quijote los separa y justifica el ardid de Basilio porque en el amor y en la guerra toda estratagema vale. Entonces Camacho se da cuenta de que Quiteria no era para él y se conforma con Narcisa, mientras se dan también las manos Perico y Antona. Las líneas generales de la acción son las mismas en las cuatro obras.

La segunda etapa de la reconstrucción del episodio cervantino la representa Las bodas de Camacho el rico de Meléndez Valdés publicada en 1784 aunque estaba redactada desde varios años antes. A pesar de que también ahora aparezcan los personajes de Petronila, prima de Quiteria y su padre, Gough LaGrone rechaza la posibilidad de una influencia debida a la Zarzuela ${ }^{13}$. Lo que se impone es la evidencia de que la introducción de esos personajes era necesaria para la lógica del tratamiento del asunto de las bodas, y también es seguro que los autores siguientes se inspiraron directamente en Meléndez: y la aportación de éste consiste en haber enriquecido el elenco de personajes con Camilo, mantenido en las demás versiones, amigo de Basilio y auténtico deus ex machina de la situación, que en cambio no era necesario para el episodio cervantino. Otra novedad de Meléndez es la intervención del mago, que tampoco estaba en Don Quijote, con lo que se refuerza la tesis de que Las Bodas de Camacho sirvieron para transmitir un mensaje nuevo y necesitaban de personajes nuevos.

Como el texto de Meléndez es el de mayor enjundia literaria e ideológica, se lo puede tomar como referente principal del asunto en el siglo XVIII, haciendo notar las variantes que se dan en las otras comedias. A diferencia de la Zarzuela, Meléndez desde luego no presenta a Don Quijote como personaje burlesco; cuando amo y escudero razonan acerca del caso de los dos amantes contrariados, el caballero toma la defensa de Basilio, mientras que Sancho se coloca del lado de Camacho razonando como el escudero cervantino:

\author{
Yo me atengo \\ al ricote Camacho: muy bien hizo \\ la zagala en cogelle; \\ no sino estar sin blanca y por las nubes \\ quiere luego casarse: cada oveja \\ vaya con su pareja (p. 18).
}

y entonces Don Quijote le contesta también como su modelo:

Calla, calla,

Sancho hablador, que tú como villano

sirves al interés (p. 19).

Esta coincidencia con el original es buscada por Meléndez porque después le servirá para desarrollar su idea del amor desinteresado. Por la misma razón, al igual que en original, en la comedia Sancho no es insensible a la abundancia de platos y manjares y Meléndez mantiene la contraposición entre las 
miras más desinteresadas del caballero y el materialismo grosero del escudero, pero escribe precisamente para desenmascarar la mentalidad subyacente en la respuesta de Sancho:

\section{El dar peñas quebranta: los dineros} vuelven en Caballeros (p. 25).

En la Comedia Pastoral se mantiene la desesperación de Basilio y sus confesiones con Camilo, quien una vez más lo empuja a hablar con Quiteria. Cuando Don Quijote y Sancho entran en escena el joven desafortunado explica su triste situación, lo que hace que el caballero proclame otra vez su rechazo de los valores mercantiles burgueses:
que está el mundo equivocado
en preferir las riquezas
a la virtud, brío y garbo.
De todo el interés triunfa,
ni somos más estimados
que lo que en el lucimiento
ostenta el lujo y el fasto (f. 13v.).

e inmediatamente, con su lógica alucinada, toma partido contra la codicia de Bernardo, padre de la muchacha:
Digo que obra como ruin,
y que yo a pie, o a caballo
sustentaré la demanda
cuerpo a cuerpo y brazo a brazo (f. 14).

En esto la Comedia Pastoral sigue a Cervantes y también a Meléndez.

Otra diferencia con la Zarzuela, y por supuesto con el original, es que a partir de Meléndez Basilio no es capaz de tomar las riendas de la situación y se muestra indeciso, muy alejado del joven doliente pero arrojado de Cervantes; el tercer acto de Las Bodas empieza con una entrevista entre los dos amantes, concertada por Camilo, mientras que la Zarzuela no había necesitado de este tercero porque el enamorado pobre tenía bríos suficientes como para pelear con Camacho. Pero la escena del parlamento entre Basilio y Quiteria es algo más que una discusión de enamorados que se echan recíprocamente en

13. Gough LaGrone, op. cit., pp. 53-56. Palacios Fernández, "Introducción" a Meléndez Valdés, Obras completas cit. III, pp. XVI-XVII. "Meléndez modificó bastante la narración cervantina, incluyendo una mujer más, con lo cual la intriga pasaba de triangular en Cervantes (Quiteria frente a Camacho y Basilio) a bipolar doble (Quiteria y Petronila frente a Basilio y Camacho), es decir Meléndez aceptaba el tipo de intriga característico del teatro español de capa y espada del siglo XVII, creando para ello un personaje que no estaba en el Quijote" en palabras de Caso González, "La literatura..." cit. p. 576. Astorgano ABAjo, op. cit., p. 99 usa la misma terminología sin indicar de quién procede. Más abajo se verá que esta comedia también se puede interpretar como tres (Quiteria, Petronila, Basilio) o incluso cuatro, añadiendo a Camilo, contra Camacho. 
cara sus faltas, y levanta el velo de unas relaciones que se antojan más tumultuosas de lo que la novela decía y la Zarzuela ya había hecho barruntar. Se queja Quiteria:

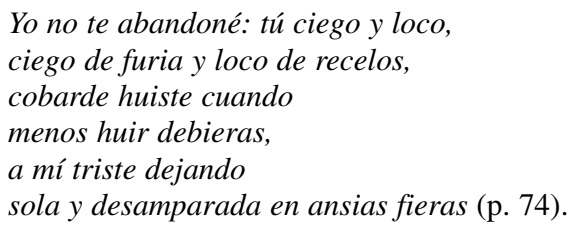

La felicidad de Basilio al enterarse de que Quiteria lo amaba a él y no a Camacho se apaga a causa de su poca iniciativa, tanto es así que Camilo ha de intervenir nuevamente para afearle su indecisión y también para sugerirle que tenía un plan que no se atrevía a formular:

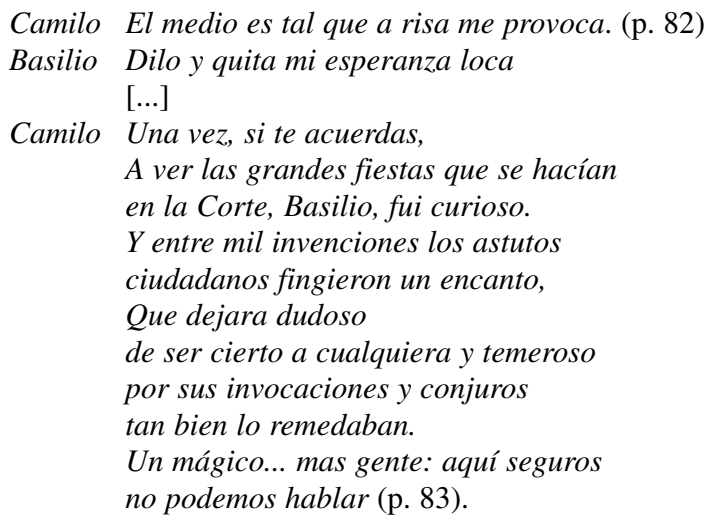

Meléndez mantiene el detalle de que Sancho, que había oído la conversación entre los dos amigos, vaya a contarla a Don Quijote. El caballero se encoleriza porque no podía concebir traición semejante por parte de una zagala honesta:
¡O Sancho! ¡Sancho!
Eso no puede ser: yo no lo creo.
Tú eres un vil, un sandio, malicioso,
descompuesto, ignorante,
mal mirado, infacundo y atrevido.
¡Así de las doncellas hablar osas
en la presencia mía!
Esto quédese aquí (p. 88).

Rasgo característico de la comedia de Meléndez es su sentimentalismo, acentuando por ejemplo la desesperación de Petronila al ver que de efectuarse los esponsales perdería a su amado Camacho definitivamente, mientras Camilo aconsejaba a Basilio que buscara el amparo de Don Quijote. No era con- 
tradictorio con su plan porque para que llegara a buen puerto iba a necesitar precisamente de la credulidad y de la autoridad... ¡de un loco! El caso es que dice de Don Quijote

Es cortés, es discreto y comedido;

$y$, o mi ingenio me engaña,

o tú has de haber por su locura extraña

remedio en tu locura (p. 98).

Un loco hace ciento y ahora un loco ayuda a otro. La idea central empieza a presagiar la locura de amor, de ese amor que poco tiempo después se llamaría romántico, que se va apareciendo por el revés de la trama ${ }^{14}$. Aunque la apreciación de romanticismo puede ser discutible, el clima cultural y el uso de elementos significativos apuntan hacia este movimiento, sin olvidar que el sentimentalismo arraigado entre los neoclásicos llevaba in nuce la nueva estética. En otra faceta de la acción de las Bodas, cuando Basilio en IV, 3 demuestra su desesperación, se pone en marcha lo que más tarde sería la imaginación romántica al contar que, cuando estaba a punto de arrojarse por un barranco, se le había aparecido un misterioso anciano que le sugirió pedir auxilio a Don Quijote. El ambiente que Meléndez ha presenta ha cambiado repentinamente de lo pastoril a lo gótico, con su toque de fantasmagórica visión y profecía nefasta: Basilio conseguiría la mano de Quiteria mas moriría a continuación. Cierto es que este elemento tampoco puede considerarse novedad absoluta, pues bastará pensar al recurso a los espíritus o fantasmas y al ambiente de sepulcros que un racionalista como Voltaire había usado en varias de sus tragedias, tragedias que se estaban traduciendo al español en los mismos años en que se escribían las Bodas de Camacho ${ }^{15}$ para caer en la cuenta de que las fronteras entre sentimentalismo neoclásico y romanticismo no se pueden trazar tajantemente. Volviendo a la comedia, huelga decir que al oír la narración de Basilio Don Quijote la cree a pies juntillas aunque Sancho tenga sus dudas, tanto es así que riñe a su amo por mezclarse en amores ajenos y defiende una vez más a Camacho por ser rico y poderoso. Incluso tacha al caballero de desleal, puesto que pagaba con tales actos la hospitalidad de Camacho y Don Quijote debe defenderse de la socarronería de su escudero:

\footnotetext{
Yo ingrato no le soy, porque le prive por un mínimo instante de Quiteria, mientras muere Basilio mal ferido.

Sancho ¿Pues lo habéis creído? (p. 112).
}

14. A propósito de Romanticismo y Neoclasicismo, véanse los estudios de SEBoLD, Russell P. Jovellanos, dramaturgo romántico y Sobre el nombre español del amor romántico en la edición digital www.cervantesvirtual.com.

15. Recuérdense aquí solamente Mahomet en las traducciones de Solís y Ledesma, o Sémiramis traducida por Zavala y Zamora, en las que aparecen sepulcros y espectros. En Mérope la desventurada reina iba a ser atada al cuerpo de Epitides "hasta que el cadáver mismo / O vil te llegue a matar". (Trad. de A. Bazo). Por cierto es curioso considerar que el mismo Valladares autor de la Zarzuela traduciría en 1788 la Alzire de Voltaire. 
El aspecto mágico de la comedia se abre en el quinto acto cuando, al punto de empezar la ceremonia, aparece Basilio y la acción se desarrolla como en la novela hasta la escena 4 en que

Camilo sale repentinamente de entre la enramada, con cuanta ilusión pueda, sin faltar a lo verosímil, vestido de mágico, como le pintó Basilio en la escena III del acto antecedente. La cabellera muy larga y cana, la barba hasta la cintura cana igualmente, negra la túnica y un bastón negro y nudoso en la mano" (p. 127).

En la Comedia pastoral las diferencias con la versión de Meléndez son mínimas: "Ábrese un Árbol y sale el Encantador; que es Camilo con el mismo traje que le pintó Basilio en la Escena 3. a del acto 4. "' (ff. 76-76v.), esto es cuando contaba a Don Quijote la visión que había tenido:
La barba hasta la cintura tendido un luengo cabello de nieve por la ancha espalda, el rostro alegre y sereno en medio de las arrugas con que le araba ya el tiempo, resplandecientes los ojos por entre nevados cerros, la nariz, larga y bien hecha todo un venerable aspecto (f. 61).

La gran diferencia es que aquí el mago cura a Basilio y Camacho quiere castigar esa "burla", mas para Don Quijote, que había creído totalmente la ficción, se trataba de "decretos de los Cielos" (f. 78) y se hace garante de las bodas de los dos amantes contrariados. Sancho Panza se toma entonces la responsabilidad de desengañar a Camacho de los amores no correspondidos y de los peligros de los matrimonios impuestos, pero aunque el espectador podría temer que recurriera a su caterva de refranes, el escudero se muestra muy comedido y sólo alcanza a razonar:

\section{Que la cabra tira al monte $y$ los amores primeros duran que te durarán}

por lo que aconseja al novio abandonado que aceptara el amor de Petronila. Así todos se casan y todos contentos, menos el espectador, porque no le explican cómo había sido el embeleco de la falsa herida de Basilio. Tal vez el autor daba por sentado que el episodio era de sobra conocido en su versión original.

En El amor hace milagros llegan por fin los novios y hace su aparición Basilio "de entre los árboles apresuradamente, vestido de un sayo negro, gironado de carmesí a llamas, coronado de ciprés y con un gran bastón en la mano" 
con lo que la comedia sigue los hechos de la novela hasta la conclusión. En Meléndez Camilo se presenta diciendo que era el "sabio Alberto" prácticamente omnipotente, aparecido para rescatar a Basilio de las garras de la muerte y todos menos Camacho creen realmente que haya habido un encantamiento cuando el joven herido sana milagrosamente de su presunta estocada; ahora es cuando Don Quijote juega el papel que Camilo había calculado para él, porque cuando los bandos de los amigos de Camacho y de Basilio están a punto de enfrentarse con las armas en la mano el caballero se pone entre ellos pidiendo silencio con "espantables voces". Así se impone la autoridad de la imaginación sobre la racionalidad de los hechos y aún más cuando el Mágico Alberto se dirige a Camacho "con voz misteriosa y levantada" para revelarle que otra muchacha estaba enamorada de él. Como era previsible, el rico burlado decide pedir la mano de Petronila y sólo cuando todos los avatares han concluido satisfactoriamente Basilio explica la artimaña con la que había conseguido que lo creyeran herido de muerte. La aparición del venerable viejo es un recurso tan peregrino y tan fuera del planteamiento original de las Bodas de Camacho que su sola mención es suficiente para demostrar que El amor hace milagros y la Comedia Pastoral son inspiración directa del texto de Meléndez.

En las cuatro piezas los autores introdujeron algunas variantes de datos y de acciones entre las que está, como se ha visto, el recurso al mágico para curar milagrosamente a Basilio de su inexistente herida. No es menos importante poder contar con una hermana/prima de Quiteria y esto por dos razones: para asegurar una mujer al novio burlado, manteniendo el tópico final de las comedias de enredo con una pareja para cada galán, típico en los siglos XVII y XVIII, y también para que las dos jóvenes puedan discurrir de los asuntos del matrimonio. Dos cosas en cambio han quedado invariadas en todas las obras, como si ejercieran especial fascinación en los espectadores y autores: los coros y bailes de los villanos y la descripción de la comida destinada a la celebración del banquete con el consiguiente entusiasmo por parte de Sancho Panza. Este último punto es claramente de raigambre popular y por lo mismo disonante en Meléndez Valdés, quien aunque reducido lo conserva igualmente, como se ha visto, señal del favor que gozaba entre el público. Las diferencias de planteamiento con el original cervantino son importantes para entender la doble oposición dieciochesca por una parte entre sentimiento amoroso puro con el mundo del interés y del cálculo matrimonial y por otra del mundo idílico de la novela pastoral con la realidad social.

Habrá que centrarse ahora en determinar en qué consiste la novedad del planteamiento dieciochesco de las Bodas de Camacho, tal y como se plasma desde la primera Zarzuela en 1772. Siendo tan semejantes las tres redacciones de Meléndez, Gómez Labrador y la Comedia Pastoral, sólo será preciso comparar la Zarzuela de 1772 con las Bodas de 1784. Los puntos en que la novela cervantina y sus adaptaciones teatrales se separan más son la introducción de nuevos personajes y en su intervención a favor de los amantes contrariados, así como el apocamiento de Basilio, que en el original no necesitaba de nadie para conseguir su fin. Estos rasgos están presentes en las cuatro obras, mien- 
tras que las tres versiones últimas han depurado algunos puntos de la Zarzuela más propios del teatro áureo que de la Ilustración: el encuentro/choque de Basilio y Camacho casi acabado en duelo, la confrontación grotesca de Don Quijote con Leandro padre de Quiteria, las bodas cómicas de Antona y Perico. La ambientación pastoral no es un elemento gratuito en la puesta en escena de la comedia, sino que tiene un peso importante en el mensaje que se deseaba transmitir. Para Cervantes, el episodio de las Bodas de Camacho era la constatación del final de la novela pastoral; ahora, en el Dieciocho, la ambientación silvestre quiere señalar la imposibilidad de acontecimientos semejantes, o más bien que han sido superados por la realidad ${ }^{16}$. Los núcleos de articulación de la acción están repartidos de manera distinta, en la trama teatral, pero son los mismos: Presentación de Basilio y sus cuitas, entrada de Don Quijote con lo que se pone al corriente al público de los antecedentes. A partir de 1784 aparecen aquí unas reflexiones de Camilo sobre las mujeres en I, 3 y la crítica de Don Quijote al interés en I, 4. Esto demuestra que desde Meléndez los autores encontraron en este punto el centro del mensaje teatral. Inmediatamente después tiene lugar el diálogo Quiteria-Narcisa/Petronila y el encuentro Basilio-Quiteria, ninguno de los cuales estaba en Cervantes y que demuestra a las claras que la Zarzuela es la base de inspiración de los otros textos. Después se asiste a las reflexiones de Narcisa/Petronila sobre su amor por Camacho, y lo que es más importante, sus pensamientos acerca de los matrimonios por interés. Por supuesto que en Cervantes no ocurrió el encuentro previo de Basilio y Quiteria pero era necesario traerlo a escena para fundamentar las razones de los dos amantes y aumentar de esa manera el sentimentalismo de la historia. Que los métodos usados para engañar al novio sean distintos o no que en el original tiene muy poca importancia, al margen de introducir elementos del gusto sentimental. La novedad del mensaje se iba a conseguir mediante los añadidos al episodio cervantino.

El núcleo del mensaje son los encuentros entre los amantes Basilio y Quiteria y las constantes entrevistas entre los varios personajes implicados en la trama. Por ejemplo en la escena tercera del segundo acto sale Basilio y Narcisa razona con él sobre la manera de conseguir que cada enamorado se quedara con quien amaba; el muchacho no encuentra solución, pero la zagala sí, aunque no quiere decírsela todavía. En la escena catorce del mismo acto, Antona consuela a Narcisa y la Zarzuela pone en escena a dos muchachas haciendo todo lo posible por encontrar marido. Canta Narcisa:

16. Para el análisis del capítulo cervantino, véanse ZIMIC, Stanislav, “El ‘engaño a los ojos' en las bodas de Camacho del Quijote". Hispania, a journal devoted to the interests of teachers of Spanish, 55, 1972, 881-886; Bulgin, Kethleen, “'Las bodas de Camacho': The Case for el Interés", Cervantes, 3,1, 1983, pp. 51-64; REDONDO, Agustín, "Parodia, creación cervantina y trasgresión ideológica: el episodio de Basilio en el Quijote", Actas del segundo coloquio internacional de la asociación de cervantistas, Barcelona, 1991, pp. 135-148; ID. en CERVANTES, Don Quijote de la Mancha ed. F. Rico, Volumen Complementario, Barcelona, Crítica, 1998, pp. 144-145. VIVAR, Francisco, "Las bodas de Camacho y la sociedad del espectáculo", Cervantes, XXI, 1, 2002, pp. 83-109. 


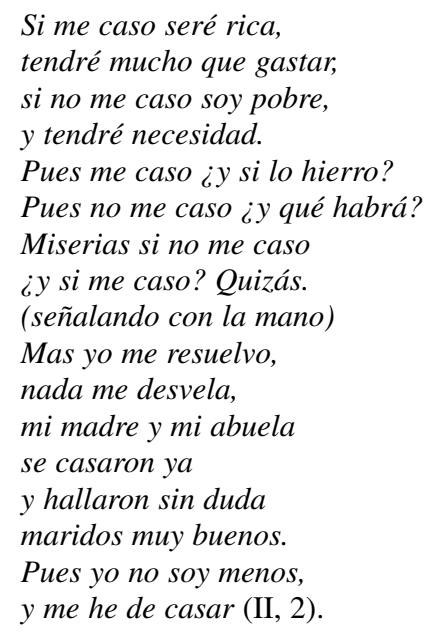

Y sigue "Todo lo he de aventurar / por casarme con quien quiero". Narcisa se plantea el matrimonio con los mismos supuestos que Sancho defendía al rico Camacho; en el fondo ambos eran villanos. A renglón seguido Don Quijote hace un discurso medio sermón sobre los deberes en y del matrimonio con lo que se precisa exactamente aquello de lo que se trata en la comedia: el espectador presencia un problema pequeño burgués ya muy alejado de la épica caballeresca y de los pastores enamorados. Don Quijote no defiende solamente el sacramento sino que también diserta acerca de las responsabilidades recíprocas de padres e hijos en el momento de dar y tomar estado, que era un motivo de preocupación concreta para la sociedad dieciochesca y el hecho de que sea un loco quien defiende la institución matrimonial no es más que una indicación -otra- de que el modelo idílico y el de la absoluta autoridad paterna han periclitado sin remisión. Ya no es válida la actitud tradicional de un "tacaño vejete" que

con violencia hoy la casa con Camacho; ella lo siente pero obedece a su padre mas Basilio el juicio pierde.

Don Quijote se indigna:
¿un amante despreciado
por los viles intereses
de un tirano padre que usa
de un dominio que no tiene?

Se plantean los límites de la autoridad paterna en asuntos de matrimonio y aquí está uno de los aspectos nuevos de las comedias de las Bodas, porque la puesta en discusión de las decisiones paternas se realiza desde el punto de 
vista de lo razonable. Las entrevistas y los monólogos de los personajes no hacen más que reiterar con sentido común los resultados de las uniones mal concertadas en las que la riqueza de una parte obliga a la otra por cálculo. Y el otro pilar de la crítica dieciochesca como se manifiesta en las Bodas aparece ahora: la riqueza no puede ser señal de superioridad moral entre los hombres porque con aplicación y estudio todos pueden alcanzarla. Hay que entender así las palabras de Don Quijote en la Comedia Pastoral,

\author{
¿Piensas tú que esas riquezas \\ de que hoy blasona Camacho \\ fueron del modo adquiridas \\ con que las trata ahora su Amo? \\ Estas riquezas y todas \\ cuantas traen alterado \\ el orden de aqueste mundo \\ con mal permitido fasto, \\ son frutos de los sudores, \\ del mantenimiento parco, \\ del trabajo y mal vestido \\ duro lecho y sueño escaso. \\ Mira tú siendo Basilio \\ de tales prendas dotado \\ si con maña y diligencia \\ podrá exceder a Camacho \\ en riqueza con el tiempo \\ como ahora en partes de hidalgo (ff. 14v.-15).
}

El mensaje muestra un asomo de crítica social y política inesperado y no visto antes, cuando el caballero alecciona a su escudero a propósito de los orígenes de la riqueza como se los entendía desde un punto de vista burgués. Éste es el punto programático racional de la Ilustración, auque mil veces desmentido en la práctica mil veces repetido en los mensajes ideológicos.

Todo lo ahora dicho queda ratificado por la exclamación de Basilio, al conseguir la mano de su amada, tras la treta de su falsa herida:
No hay más milagro
que industria y maña dispuesta
para este logro a pesar
del poder y la riqueza (f. 50).

El peso del poder y de la riqueza, derrotados por la iniciativa de la industria, transposición de los ideales ilustrados del campo de la política al de las relaciones afectivas, la nobleza de cuna superada por la burguesía emprendedora. Sin embargo, al igual que en la defensa de lo razonable hecha por un loco, aquí también aparece la ambivalencia del mensaje, pues la defensa de los ideales mercantiles se pone en boca a un loco. En la solución que las comedias dieciochescas dan a las mal avenidas bodas de Camacho hay puntos de ambigüedad que no se pueden soslayar, que enriquecen su planteamiento, pero 
que no son concluyentes, pues es cierto que se ha derrotado el cálculo interesado, pero ha sido con otro tipo de cálculo, la intriga de los enamorados a espaldas del padre de la chica y del novio. La misma actitud de calcular y planear acciones para conseguir sus fines es la de los enamorados en la comedia de Gómez Labrador, pero con la ambigüedad que aparece ahora por otras consideraciones muy notables. Cuando Quiteria se pone en manos de Basilio, lo hace con una condición, que está dispuesta a seguir

\author{
alguna invención o traza \\ para que pueda ser tuya, \\ sin dejar de ser guardada \\ la veneración que debo \\ a quien debo la sustancia, \\ contando con mi firmeza \\ no temas ponerla en planta (p. 19).
}

¿Ambigüedad o contradicción? Con la demostración de su triunfo Basilio y Quiteria demuestran que el amor verdadero es más fuerte que el interés, se va configurando ya como la fuerza arrolladora que será en el Romanticismo, pero la salvedad de la veneración debida a la autoridad paterna es una consideración más bien burguesa y muy poco apasionada. Es decir, que el planteamiento dieciochesco de las Bodas de Camacho oscila entre un incipiente arrojo rompedor novedoso y una muy sentimental moderación. En cualquier caso, nada parecido al idealismo caballeresco de Don Quijote.

Desde el punto de vista de esta indefinición Las Bodas de Camacho el Rico de Meléndez es la más singular de las cuatro comedias y también la más ideológicamente marcada, en la doble línea del sentimentalismo de su autor y del mensaje cultural que propone. Ya desde el principio el espectador asiste a los lamentos de Basilio porque su amada Quiteria ha sido "vendida" a Camacho a causa del cálculo del padre de ella. El joven no podía olvidarla, por más que dudara si ella lo quería:
¡Yo a Quiteria! Primero
el fuego será frío, el Sol oscuro,
y el mayo irá sin flores,
que yo la hable, ni vea.
No, zagal, yo no quiero
ponerme de la infiel a los desvíos,
ni a su intención contravenir en nada,
turbando en vano con los ruegos míos
la luz serena de sus claros ojos,
ni las purpúreas delicadas rosas
de sus mejillas (p. 15).

Las protestas amorosas se mezclan con las consideraciones sobre la pobreza de Basilio y cuando entra en escena D. Quijote depreca la riqueza con tonos mucho más duros que en el original cervantino: 


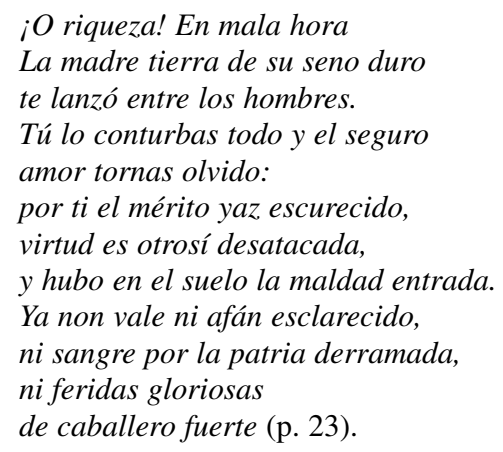

Por más que este tópico fuera moneda corriente, el binomio riqueza/matrimonio impuesto adquiere connotaciones evidentes de crítica social y moral en las cuatro obras ${ }^{17}$.

Hay un pasaje muy esclarecedor en la Zarzuela cuando Narcisa viene a animar a la novia y pone a prueba a Quiteria contándole las locuras que Basilio iba haciendo al ser despreciado y Quiteria responde
Estas faltas que le pones
tal vez serán circunstancias
para mí de mucho aprecio,
pues todas ellas me agradan.
Si es pobre, pobre le quiero;
no el interés me arrebata,
pues más que bienes del cuerpo,
quiero riquezas del alma.

Sigue la tentadora Narcisa:
¡Jesús cuánto disparate
produces en lo que hablas!
Querer por sólo querer,
no es amor, sino tontada.
Querer por utilidad
esa sí es discreta maña.

Quiteria dice a Narcisa que "piensas como villana” pero la réplica es fulminante "piensa tú como Señora, / verás por pobre, qué sacas". En relación con las otras comedias, en la de Meléndez hay una reflexión consciente sobre la fuerza del amor y la libertad afectiva, que se desarrolla en los diálogos entre los varios personajes. En II, 2 Camilo habla con Petronila de los amores contrastados y denuncia las trágicas consecuencias de

17. Aguilar PIÑal, Francisco, "Anverso y reverso del quijotismo en el siglo XVIII español", Anales de literatura española, I, 1982, pp. 207-216. ID. "Cervantes en el siglo XVIII" Anales cervantinos, 1983, pp. 153-163; VIVAR, cit. 
un lazo, que ha formado

sólo interés y paternal decoro

y defiende el matrimonio por amor (pp. 38 ss.). Además, el joven anima a Petronila a que convenza a su hermana de que suspenda las bodas en evitación de los males que tal matrimonio no podría no traer. Lo más interesante es que en la escena siguiente Petronila, una vez sola, razona que de tener Camilo razón ella podría conseguir el amor de Camacho, mezclando una vez más principios elevados e intereses personales. La Comedia Pastoral debe mucho a Meléndez, pero llegando a este punto hay que reconocer que todo el razonamiento se venía desarrollando desde 1772, en lo que se refiere a las consideraciones sobre amores e intereses. En la plática entre Camilo y Petronila queda bien claro que el interés no puede fundamentar un matrimonio decente, por lo que el joven se ve justificado a intervenir con un medio "honesto" para corregir la situación. En la Zarzuela Narcisa cuenta que Camacho y ella habían sido enamorados antes de que él se prendara de Quiteria, pero "por ser pobre / no me atreví a poner pleito". Es decir, que en la Zarzuela, en esta fase de elaboración del discurso sobre matrimonios concertados, no se atreve aún a presentar los derechos del amor por el amor y recurre a la ley y las acciones de justicia. Sin embargo más adelante, al lamentarse Basilio de que los familiares de Quiteria le eran contrarios, Narcisa le contesta

\author{
¿Y eso qué importa? Ella quiere; \\ no te andes por arrodeos \\ pesca la moza y después \\ que chillen y rabien ellos.
}

Otra vez la limitación prudencial que marca hasta dónde es lícito llegar en cuestiones de amor. Más tarde las dos hermanas hablan a raíz de lo dicho por Camilo y discurren sobre la situación de las muchachas casaderas y del nefasto peso que el interés tiene en el éxito de los matrimonios.

Los múltiples razonamientos de las comedias están trabados para ofrecer al público un discurso coherente. Los diálogos sobre la autoridad paterna remiten a la crítica de la riqueza y el interés, en base a una concepción del matrimonio fundada en el sentido común y en consideraciones prácticas.

En la Zarzuela, I,4, Quiteria responde a Narcisa defendiendo a las personas, no los caudales, con el consiguiente escándalo de la segunda, que reacciona con los pies en el suelo:

\footnotetext{
Bien se conoce que tienes

esa cabeza atestada

de novelas y de versos,

que te escribía y cantaba (f. 22).
} 


\title{
Para Narcisa
}

\author{
Allá en el siglo pasado, \\ nuestras abuelas usaban \\ enamorarse de tontos \\ sin más caudal que palabras, \\ componer algunos versos, \\ y saber dar cuchilladas: \\ pero ¿de qué sirve eso? \\ ¿Cuánto mejor empleada \\ está una mujer con hombre, \\ que la mantiene y regala? \\ Ésta es la verdad, Quiteria (f. 23).
}

En II,2, la joven sigue decidida:
Más quiero pasar por loca y casar con quien deseo, que no pasar por juiciosa, sin marido y sin dinero (f. 5).

Y canta la cancioncita de la madre y la abuela ya oída más arriba.

En las palabras de Narcisa está toda la contradicción del problema que no es como aparentemente se podría interpretar la opción amor/interés según dice en el primer acto. El nudo real consiste en saber cuál se la posición sensata, si pasar por loca o por juiciosa como se plantea en el acto II. Años más tarde esto se llamaría Sense and Sensibility.

En contraposición al ambiente idílico de la novela, las comedias de las Bodas se anclan a la realidad con detalles para reconducir las justas dimensiones de la acción. En la Comedia Pastoral Petronila recuerda a Quiteria que las muchachas que no se casa estando en edad "tienen mal nombre en el Pueblo" (f. 26) con lo que se abre otra línea de razonamiento sobre la libertad de las mujeres -que los textos no amplían- ofreciendo las primeras señales de la existencia de tal problema. Para desarrollar la reflexión sobre los males de los matrimonios fundados en el interés los autores se han valido de la oposición de opiniones entre el personaje principal, Quiteria, y su confidente ya se llamara Narcisa o Petronila. Es la misma radical oposición que en la novela representan Don Quijote y Sancho. En Meléndez:

\footnotetext{
Petronila Es la riqueza puerta de contento y la cruda pobreza puerta de desventura, cuando amor cesa y queda su amargura. Amor, cual niño alegre, risas y juegos y donaires ama, cuanto pobreza lloros, que al punto apagan su celeste llama. (v. 85).

Camilo No, gentil Petronila,
} 
ni mísera fortuna ni pobreza

de un pecho fiel apagan la fineza.

La inclinación, el gusto,

la unión de voluntades

decretada del Cielo,

las sencillas verdades,

de agradar el solícito desvelo,

esto solo es amor y a los esposos

ciñe la sien de flores

que jamás se marchitan ni desdicen

sus primeros verdores,

lo demás es dureza y tiranía (v. 98).

Razonamiento que en la Comedia Pastoral suena así:

Camilo Petronila eso es muy cierto:
Mas ni la riqueza forma
La dicha de un casamiento,
Ni la pobreza se opone
A sus felices progresos.
La unión de dos voluntades,
Amor mutuo y verdadero
De dos amantes es causa
De su gran dicha y contento.
Éste es aquel gran milagro
Con que conservarse vemos
Innumerables familias
De la pobreza en el seno.
Y éste me mueve a aplicar
Por Basilio mis esfuerzos,
Por si su mortal desgracia
Puede hallar algún remedio (f. 23 v.).

Huelga repetir las exclamaciones de otros personajes en las demás comedias. En Gómez Labrador Camilo defiende la felicidad matrimonial por encima de los bienes de fortuna (f. 23v.).

La variedad de lecturas que tiene el mensaje de las comedias presenta entonces y de inmediato otro problema, a saber si se está hablando de amor o de matrimonio. Pasión atrevida es la de Basilio en la Zarzuela, cuando exclama

Pues si Quiteria me quiere, para mi amor poco importa que su padre no consienta y quiera impedir mis bodas; si no me quiere es inútil forzar la voluntad propia $(\mathrm{I}, 10)$. 
En la Comedia Pastoral, III,4, el encuentro de los dos amantes concluye con promesas de morir el uno por el otro. Es una manifestación de sentimentalismo rayana en la exaltación típica de los románticos ${ }^{18}$ que en Meléndez afligía a Basilio y lo llevaban a querer darse muerte:

\author{
El más impío \\ furor, la más rabiosa \\ determinada voluntad que pudo \\ caber en pecho de pastor \\ mas ahora quiero \\ que ante sus ojos sea, \\ y que la ingrata vea \\ en el momento de sus tristes bodas, \\ con qué extremo la amaba \\ este desventurado (vv. 225-230).
}

Gómez Labrador presenta a un pastor despechado y deprimido:

\author{
mas si vieras \\ con qué fuerza penetrado \\ está el ánimo afligido \\ de designios temerarios \\ de penas, tedio y Horror \\ de mi mismo y todo cuanto \\ registran aquí mis ojos (ff. 8r.v.).
}

Luego se está poniendo en escena un anuncio de lo que sería de allí a poco el amor romántico en sus manifestaciones más extremadas ${ }^{19}$. Un amor corregido sin embargo por grandes dosis de sentido práctico y de realismo en los consejos de Camilo a su desventurado amigo. Mientras que en las consideraciones de Narcisa o Petronila sobre la conveniencia de casar por amor o por interés el significado final podía ser ambiguo, en este caso está claro que el valor predominante es el de la acción meditada. Meléndez no admitía que la única salida de basilio fuera el suicidio por amor; Camilo decía que primero había que hablar con Quiteria y averiguar exactamente sus sentimientos. Así -decía a Basilio, la muchacha será tuya

si en vez de lamentarte

procuras ayudarla (I,2, vv. 44-45).

18. Sebold ha recordado la contemporaneidad del Werther Goethiano y de las Noches lúgubres de Cadalso. SEbold, Russell P. "El suicidio romántico", De ilustrados y románticos, Madrid, El Museo Universal, 1992, pp. 65-69, obras ambas de la misma época que las Bodas. Otra interpretación en BUSQUETS, Loreto, Modelos humanos en el teatro español del siglo XVIII, edición digital www.cervantesvirtual.com.

19. SEBold, Russell P. Sobre el nombre español del dolor romántico, edición digital www.cervantesvirtual.com. 
igual que en Gómez Labrador. No importa que el recurso utilizado fuera un engaño o la ayuda de un loco para certificar un mágico prodigioso, porque de lo que se trataba era de vencer con maña a la fuerza. Bien poco romántico parece todo esto, y menos aún lo parecen los remilgos pequeñoburgueses de Basilio:

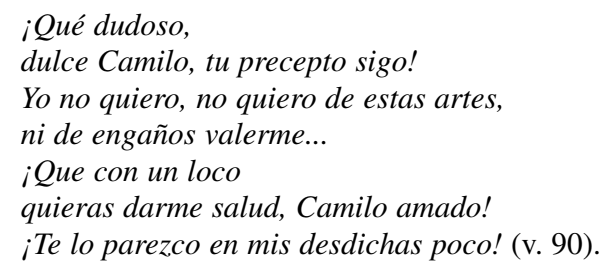

En cambio no deja de ser irónicamente exaltada la contestación de su amigo:
¿Pues qué? ¿Si así no fuera, ayudarnos pudiera?
Él es determinado y con respeto
todos aquí le miran.
Ninguno su flaqueza ha conocido.
Es cortés, es discreto y comedido;
$y$, o mi ingenio me engaña,
o tú has de haber por su locura extraña
Remedio en tu locura (vv. 91-99).

Está bien claro que en Meléndez el recurso al mágico es necesario para justificar la presencia de Don Quijote en la comedia. La acción se podía haber desarrollado perfectamente sin el caballero, pero entonces habría roto los lazos con la novela; para que Don Quijote no fuera un mero espectador debía hacerse garante de la realidad de las falsedades que estaban ocurriendo. Además se puede interpretar como una parodia de las comedias de magia tan populares aún en sus tiempos ${ }^{20}$, pero Meléndez Valdés se aleja con ello no sólo de la letra sino también del espíritu de Cervantes como ha puesto de manifiesto Aguilar Piñal.

Los términos centrales del discurso oscilan pues entre la pasión amorosa desbordada y el sentido común burgués. El anticlímax tierra a tierra lo pone la

20. Hasta finales del Dieciocho la comedia de magia "supera con regularidad todas las marcas de asistencia y duración” en el teatro madrileño. Andioc, op. cit., pp. 49 ss. CARo BarojA, Julio, Teatro popular y magia, Madrid, Revista de Occidente, 1974; PAlaCioS FERnÁndeZ, Teatro... cit. GARCÍA DE ENTERRÍA, María Cruz, "Magos y santos en la literatura popular (supersitición y devoción en el Siglo de las Luces", Al margen de la Ilustración. Cultura popular, arte y literatura en la España del siglo XVIII, ed. J. Huerta Calvo - E. Palacios Fernández, Ámsterdam, Rodopi, 1998, pp. 53-76; ÁlvarEZ BARRIENTOS, Joaquín, "Teatro y espectáculo a costa de santos y magos”, Al margen de la Ilustración. Cultura popular, arte y literatura en la España del siglo XVIII, edición Huerta Calvo - Palacios Fernández, Ámsterdam, Rodopi, 1998, pp. 77-96. También el estudio de MATA IndurAin, Carlos, "Don Quijote de la Mancha resucitado en Italia. Comedia de magia burlesca", Anales Cervantinos, XXXV, 1999, pp. 309-323. 
prudencia de los amantes, en palabras de Gómez Labrador. Camilo le indica que Quiteria lo amaba; pero Basilio responde:

\author{
¿Qué hacemos con esto Amigo? \\ ¿No es este día en que estamos \\ el de las bodas? ¿La misma \\ Quiteria que desdeñando \\ está tal vez con ficciones \\ al venturoso Camacho, \\ no le ha dado ya palabra \\ de ser su Esposa? ;Qué agravio! (f. 10).
}

Es muy parecido el razonamiento en Meléndez, II,2, y hay que recordarlo porque la reiteración de esa idea es significativa de la mentalidad del momento:

Tuya soy; busca modo

como esto pueda ser sin que yo falte

al paternal respeto,

ni a la ley del recato.

¡Bárbara ley!...

Para Meléndez Valdés y Gómez Labrador, hombres de leyes, el límite de la acción estaba aquí, en que no se podía poner en duda la palabra ya dada. Un auténtico romántico habría raptado a la muchacha, un barroco la hubiera matado, un burgués sentimental podía engañar, pero su obstáculo era el contrato de palabra. En otro momento de la misma comedia, cuando Quiteria se entera de que su amado estaba vivo (f. 28) acepta la entrevista que le ofrece Petronila, con la salvedad de "mas si se sabe..." (f. 29). Muestras de prudencia poco heroicas. Es precisamente el continuo llamamiento a la acción comedida lo que crea la ambigüedad de la trama en las Bodas. Gómez Labrador hace que Camilo exponga a Petronila la situación y el peligro de que Basilio pensara quitarse la vida pero la muchacha, al oírlo, demuestra una frialdad de juicio inesperada.

Con todo eso me parece, que en llegando a estos extremos, debe obrar más la prudencia que nuestros propios afectos. Mi hermana sola pudiera $Y$ aun debiera a su provecho Atenta sólo y al gusto

De su padre, esposo y deudos, Con su buen juicio y con maña

Evitar los sentimientos

Que pueden tener tan malas

Consecuencias con el tiempo.

Harto ha sido venturosa, 
Pues le ha preparado el Cielo

Grande ocasión de vivir

Con regalo y lucimiento

En la mayor opulencia (ff. 23r.-v.).

Nótese que mientras está tramando la manera de echar a perder la boda concertada la joven no olvida ni calcular las posibles consecuencias ni ponderar la suerte de un casamiento con dinero. Este continuo vorrei e non vorrei no es un matiz propio de Gómez Labrador sino por el contrario la esencia del planteamiento ideológico y de sensatez el teatro y en la sociedad que lo alejan de los excesos románticos como ha puesto en luz Loreto Busquets ${ }^{21}$. De hecho, pocos versos más abajo, la misma se pregunta

Si ves que por esta parte

Hay de amor tantos extremos,

$Y$ por la otra no hay amor

Sino violencia y respetos;

¿No será decente y justo

Procurar con todo esfuerzo

Que se evite? (f. 24).

Evitar la boda desastrada era entonces admisible aunque fuera atentando a la autoridad del padre y se podía justificar porque éste no se movía más que por interés. Así lo había dado a entender Cervantes y así lo subrayaban los autores de las comedias. Gómez Labrador lo afirmada rotundamente en I,4,

Mas no se deja en el Pueblo

de murmurar que Bernardo

que es el padre de la novia

del interés sea llevado;

pues pudiera dar esposo

igual a Quiteria y harto

más rico de buenas prendas

si de bienes más escaso.

En la Comedia Pastoral lo declara Quiteria con todas letras:

y si al cabo las instancias,

y los repetidos ruegos

de Camacho han conseguido

ver mi albedrío sujeto,

no a sus riquezas, hermana,

21. BusQuETS, op. cit. "La verdad es que ninguna figura femenina (ni masculina) de las comedias que he estudiado, conoce un amor capaz de superar o quebrantar los obstáculos sociales que halla a su paso, de desacatar la autoridad, y sobre todo de violar la ley suprema del orden burgués: la obediencia a los padres. Se respeta, eso sí, la "natural inclinación", pero al término amor, que sugiere desbordamiento y desestabilización, se prefiere el de afecto y cariño". 
ni a ningún otro embeleso mi voluntad se ha rendido mas de mi padre el precepto, a cuya obediencia humilde rindo yo mis pensamientos (ff. 25v.-26).

Lo más importante es que el caso de Quiteria es solamente una parte de la realidad femenina en general:

Por lo regular tan sólo

Forma nuestros casamientos

El interés; la que tiene

Tal cual crianza y talento,

No puede mostrar ninguna

Repugnancia la nuevo empleo,

Aunque la entreguen a un hombre

Que la repugne; no hay medio,

Se ha de casar como en venta,

Dándose al mucho dinero.

Como los padres esperan

Su parte en debido premio,

De lo que arriesgan la hijas

Hacen poca cuenta ellos (ff. 26v.-27).

La Zarzuela, con su carácter más arcaico, tiene una escena en la que el padre Leandro casi se justifica ante Quiteria. Es en I,8, y aunque la imposición paterna tiene una base económica, se intenta hacer valer el peso del honor para que la muchacha se doblegue:

\author{
conque mira si podrás \\ abandonarle por otro. \\ El honor es lo primero, \\ y en empeño tan forzoso, \\ está tu honor empeñado, \\ siendo el dejarlo afrentoso. \\ [...] \\ Olvida estos devaneos, \\ $Y$ acuérdate de que sólo \\ debes dar gusto a tu padre \\ que lo demás es impropio (ff. 39-40).
}

Oyendo o leyendo estas palabras no cabe duda que se está planteando la justificación de la desobediencia de los hijos ante las decisiones de sus padres en lo que atañe a tomar estado. Eso estaba también presente en Cervantes, con una ambigüedad no menor, puesto que la treta de Basilio en ningún momento recibe condena alguna en la novela, aunque al presentar el episodio de las Bodas de Camacho Cervantes hacía que Don Quijote negara abiertamente que los hijos pudieran elegir estado libremente. ¿Habrá entonces alguna diferencia entre la novela y las comedias dieciochescas? Sí y de peso; el caballero opi- 
naba que las hijas se casarían pensando más en la "afición" que en el "entendimiento" y serían capaces de enamorarse de cualquier mozo "bizarro" o "desbaratado espadachín" 22 . En los razonamientos de las comedias en cambio lo que las interesadas Quiteria y Narcisa/Petronila quieren evitar es precisamente el "peligro de errarse", en que las pone la falta de "tiento" de su padre. Para Cervantes los padres representan el sentido común, para las comedias del Dieciocho la autoridad ciega es un desvarío. Ahora que este planteamiento no era exclusivo de Las Bodas porque se encuentra expresado de forma magistral algunos años más tarde en El sí de las niñas:

Mira, Simón, si los matrimonios muy desiguales tienen por lo común desgraciada resulta, consiste en que alguna de las partes procede sin libertad, en que hay violencia, seducción, engaño, amenazas, tiranía doméstica... $^{23}$.

Las reflexiones arriba vistas que se reflejan en el teatro del último cuarto del siglo XVIII se encuadran en un debate social poniendo en discusión los límites de la autoridad paterna que se hace patente por los afanes del Poder por regular los matrimonios reforzando la postura de los padres. Se puede comprobar por la cantidad de medidas legales que se tomaron para poner coto a la libertad de elección de los hijos, es decir contra una cierta tímida manifestación del matrimonio por amor usando todos los resortes que el Poder tenía a su disposición; por una parte el Consejo de Castilla encargaba a la Iglesia el control social de las uniones, siguiendo el Concilio de Trento y por otra la Novíssima Recopilación recogía la obligación, expresada en 1776 y repetida en 1788, de que los hijos tuvieran el consenso paterno para casarse, en fechas que coinciden con las de las cuatro Bodas. La pieza central de todo el edificio legislativo era la Pragmatica de 1776, acompañada de una batería de medidas legales $^{24}$.

22. Cervantes, Don Quijote cit. II, XIX. "Si todos los que bien se quieren se hubiesen de casar dijo don Quijote-, quitaríase la eleción y juridición a los padres de casar sus hijos con quien y cuando deben; y si a la voluntad de las hijas quedase escoger los maridos, tal habría que escogiese al criado de su padre y tal al que vio pasar por la calle, a su parecer, bizarro y entonado, aunque fuese un desbaratado espadachín; que el amor y la afición con facilidad ciegan los ojos del entendimiento, tan necesarios para escoger estado y el del matrimonio está muy a peligro de errarse y es menester gran tiento y particular favor del cielo para acertarle".

23. Fernández de Moratín, Leandro, El sí de las niñas, I,1.

24. Pragmática sanción a consulta del Consejo, en que S.M. establece lo conveniente para que los hijos de familia con arreglo a las leyes del Reyno pidan el consejo y consentimiento paterno antes de celebrar esponsales... El Pardo 23 de Marzo de 1776. Archivo Histórico Nacional (en adelante, AHN) Consejos legajo 11933. Real Cedula de S. M. y Señores del Consejo, en que se declara y manda por punto general, que solo los hijos de familia son los que pueden pedir el consentimiento á sus padres, abuelos, tutores, ò personas de quienes dependan para contraer Matrimonio, y que no se deben admitir en los Tribunales Eclesiásticos demandas de esponsales celebrados sin el asenso paterno contra lo prevenido en la Real Pragmática de 23 de Marzo de 1776, y posteriores resoluciones, con lo demás que se expresa. AHN, Consejos libros 1364/403; 1489/3 y 2; 1523/171; 1523/179 y Estado legajo 4900/2,52; El Rey. Por cuanto por carta de doce de octubre de mil setecientos ochenta y uno mi 
En el fondo, lo que proponían las cuatro comedias era la infracción de lo establecido por la Pragmática de 1776 en la que se establecía que "Habiendo llegado a ser tan frecuente el abuso de contraer matrimonios desiguales los hijos de familias, sin esperar en consejo y consentimiento paterno", los menores de 25 años debían pedir "consentimiento de su padre; y en su defecto de la madre" (f. 5). Por otra parte el legislador era víctima de la misma ambigüedad que los literatos porque también establecía que los padres no habían de obligar a sus hijos a casarse contra su voluntad ya que la experiencia demostraba que se originaban consecuencias desastrosas (ff. 5-7) y eso es precisamente lo que se argumenta en las comedias de las Bodas de Camacho. Es llamativo es que textos legales y piezas teatrales usaban casi las mismas palabras. La Pragmática se dirigía contra la costumbre de

contraer matrimonios desiguales los hijos de familias, sin esperar el consenso y consentimiento paterno [...] opuestos al honor, respeto y obediencia que deben los hijos mostrar a sus padres, en materia de tanta gravedad e importancia

lo que era casi un eco de las palabras del padre de Quiteria; pero en su artículo VI la misma Pragmática consideraba que

ha manifestado la experiencia que muchas veces los padres y parientes con fines particulares e intereses privados [...] se resisten a consentir en el matrimonio justo y honesto que desean contraer sus hijos, queriéndolos casar violentamente con persona a quien tienen repugnancia, atendiendo regularmente más a las conveniencias temporales que a los altos fines para que fue instituido el santo Sacramento de Matrimonio.

Que parece reflejar las quejas de los amantes teatrales. Así que lo realmente llamativo, más allá de las coincidencias verbales, es la ambigüedad de fondo: había que imponer tajantemente la autoridad paterna pero también había que reconocer que

es justo precaver al mismo tiempo el abuso, y exceso en que pueden incurrir los padres y parientes en agravio y perjuicio del arbitrio y libertad que tienen los hijos para la elección del estado a que su vocación les llaman

hizo presente con testimonio mi Real Audiencia de México que don Juan Antonio López... siguió autos contra don Ramón Luis de Aranda... sobre la calificación de los motivos por que resistió el matrimonio, que aquél pretendía contraer con su hija... he resuelto declarar.. que siempre que cualquier hijo o hija de familia intentase contraer matrimonio... quedase ejecutoriado ser racional y justo el disenso del padre... Fecha en Aranjuez a veinte y seis de mayo de mil setecientos ochenta y tres, AHN, Consejos libro 1525/454; Real Cedula 6 de junio de 1784, AHN, Consejos libro 1492/342; Real Cedula 2 de enero de 1785, AHN, Consejos libro 1493/440; Real cedula 1788, AHN, Consejos libro 1379/301; AMORós, Joaquín, Discurso en que manifiesta la necesidad y utilidad del consentimiento paterno para el matrimonio de los hijos y otros deudos: conforme a lo dispuesto en la Real Pragmatica de 23 de Marzo de 1776. Un buen estudio sobre el asunto en general es FLANDRIN, Jean-Luois, Orígenes de la familia moderna, Barcelona, Crítica, 1979. 
como se hacía en los artículos VI y VIII. Los autores teatrales estaban usando sus obras para la defensa de la libertad afectiva pero representaban las contradicciones morales de los personajes porque la misma ley era indecisa. La cuestión queda zanjada definitivamente si se considera que el autor de una de las comedias de las Bodas y sobre bodas, Meléndez Valdés, en su calidad de fiscal sostenía en los tribunales lo mismo que en las tablas. Véase si no su informe en un pleito matrimonial, donde sostenía la necesidad de que el amor y no una palabra de compromiso debía ser la base de una unión tan importante.

Este vínculo [...] que no ha de contraerse sino por los sentimientos y aficiones más puras; en que deben hablar los corazones hasta el último instante tan dulce y espontáneamente, que su idioma no sea otro que el de la inclinación y la verdad [...] que cualquier coacción marchita y sofoca acaso para siempre; y en que, en fin, el hombre social debe separase cuanto menos pueda de los sentimientos de innata libertad, que tan imperiosamente hablan al hombre [...].

Meléndez se movía contra la imposición de de un matrimonio por promesa de futuro cuando era evidente que los contrayentes no se amaban. Incluso proponía que se derogara la ley 7 del Título I Partida 4. a que reconocía a los obispos la autoridad para estipular la obligación de contraer matrimonio por sentencia de la Iglesia ${ }^{25}$. En ambos órdenes de intervención pública, el teatral y el jurídico, Meléndez usaba los mismos argumentos y prácticamente las mismas expresiones.

La defensa de la libertad de los sentimientos se manifestaba también en otros escritores, como en la hermosa defensa del matrimonio por amor contemporánea de las Bodas de Camacho, hecha por Sempere y Guarinos:

Los casamientos, por razón natural, debían fundarse sobre el amor mutuo y sobre la más íntima y estrecha unión de las voluntades. Mas como regularmente suelen presidir a estos enlaces los fines de conveniencia y de falsa esperanza de aumentar fortuna, para obscurecer estas intenciones, se procura deslumbrar al público y aun a sí mismos, con expresiones desmedidas, dádivas exorbitantes y condescendencias bajas; de donde suele resultar, que frustradas las esperanzas concebidas, es más pronta y más lastimosa la ruina ${ }^{26}$.

Así que la defensa de los matrimonios por amor estaba en el ambiente cuando se escribieron las versiones de las Bodas de Camacho y no era prerro-

25. MelÉNDEZ VALdÉs, Juan, "Dictamen fiscal en una solicitud sobre revocación de la sentencia ejecutoriada en un pleito matrimonial", en Poesía y prosa, ed. J. Marco, Barcelona Planeta 1990, pp. 689-690. "El cuidado con que Meléndez sitúa los procesos judiciales en su contexto social, le permite hacer sesudos razonamientos sobre la sociedad de la época". Meléndez ValdÉs, Juan, ed. Palacios Fernández cit. III, pp. XX - XXIII. También Demerson, George, "Prólogo" a Meléndez Valdés, Juan, Discursos forenses, ed. Esteban, Madrid, Fundación Banco Exterior, 1986.

26. SEMPERE y GuARINOS, Juan, Historia del lujo y de las leyes suntuarias en España, Madrid, 1788, pp. 104-105. 
gativa, evidentemente, de los tratadistas. Se encuentra ente otras muchas obras en un pasaje contemporáneo de Cadalso, al referir la carta de la muchacha que se lamentaba de haber sido seis veces viuda, lo que habría podido evitar de haberse casado según su "gusto, en lugar de sujetarlo seis veces al de un padre que cree la voluntad de su hija una cosa que no debe entrar en cuenta para el casamiento". Sempere y Guarinos recordaba también que D. Ramón de la Cruz había traducido, entre sus "comedias extravagantísimas", "El matrimonio por fuerza”, de Molière. Y Moratín con El sí de las niñas seguía elaborando el mismo tema ${ }^{27}$.

La moral, tal y como la reflejan los sermones, en cambio, abogaba por un control de las uniones, cuyos fines en ningún caso debía ser "los de la lujuria, sino la propagación del género humano y el remedio de la incontinencia" ${ }^{28}$, o según la Iglesia católica, como rezaba el Tratado VI, demostración "Del honor que se debe a los padres" 29 . No se debe pensar que las afirmaciones en favor de la autoridad paterna fueran exageraciones del pensamiento autoritario. De un examen superficial de los libros de registro del Consejo de Castilla se pueden encontrar, para el período de 1776 a 1800, quince pleitos por promesa de matrimonio, uno por matrimonio clandestino, siete por no respetar el permiso paterno y tres por desavenencias conyugales ${ }^{30}$.

El tema de la autoridad paterna y del interés van estrechamente unidos a otra línea de pensamiento, es decir la crítica de la riqueza por la violencia que ejerce en las relaciones sociales. De nuevo los autores de las comedias se inspiran en la novela, en las palabras mismas del caballero andante cuando condenaba la virtud acomodaticia de Sancho ante los ricos y poderosos, pero como no podía ser de otra manera también queda este punto del mensaje cervantino abierto a múltiples posibilidades representadas por las ideas ruines pero en el fondo sensatas de Sancho Panza, por ejemplo:

Yo apostaré un brazo que puede Camacho envolver en reales a Basilio; y si esto es así, como debe de ser, bien boba fuera Quiteria en desechar las

27. Cadalso, José DE, Cartas Marruecas, 1774 carta LXXVI, pp. 263-264. SemPere y GuARINos, Ensayo... cit. Otro escritor del Dieciocho, continuador de las aventuras de Don Quijote, también asumía que el episodio de Crisóstomo y Marcela en la novela tenía por objeto condenar la libertad de elección de los hijos en asuntos de matrimonio. GATEll, Pedro, La moral de Don Quijote deducida de la historia, que de sus gloriosas hazañas escribió Cide-Hamete Benegelí. Por su grande Amigo el Cura. Dala a luz el B[achille]r. D.P. GATELL, Madrid, por Josef Herrera, 1789. La moral del segundo libro pp. $101 \mathrm{ss}$.

28. Fray JuAn de Murcia, Sermones, Barcelona 1755, 98, n. 5.

29. EChARRI, Francisco, Directorio moral, Murcia 1769, III, nn. 214 ss. Excelencias del matrimonio, y obligaciones de las personas que abrazan este estado: probadas con autoridades en la Sagrada Escritura, Concilios, y Santos Padres / traducido del francés por.. Don Pedro Díaz de Guere$\tilde{n} u . .$. de la Congregación de Clérigos Reglares de San Cayetano; Madrid, Pedro Marín, 1776. LoRENZANA, Francisco Antonio DE, Nada apetece con mas ansia el buen padre de familias, que la sucesión á toda su posteridad, pues con ella se perpetúa su memoria, se conservan las casas, logran los casados el mas estrecho vínculo de la paz, el consuelo de sus hijos, y todo el linaje humano se interesa en el fruto del matrimonio y su lícita propagación... AHN Clero secular y regular. Leg. 3693.

30. AHN, Consejos libros 830 y 1364. 
galas y las joyas que le debe de haber dado y le puede dar Camacho, por escoger el tirar de la barra y el jugar de la negra de Basilio. Sobre un buen tiro de barra o sobre una gentil treta de espada no dan un cuartillo de vino en la taberna. Habilidades y gracias que no son vendibles, mas que las tenga el conde Dirlos; pero, cuando las tales gracias caen sobre quien tiene buen dinero, tal sea mi vida como ellas parecen. Sobre un buen cimiento se puede levantar un buen edificio y el mejor cimiento y zanja del mundo es el dinero ${ }^{31}$.

Y se recogen tales y cuales en las comedias, teñidas de los ideales ilustrados, lo que les da un alcance nuevo. Gómez Labrador pone en boca a Basilio y Camilo las dos opciones fundamentales: lamentarse o reaccionar.

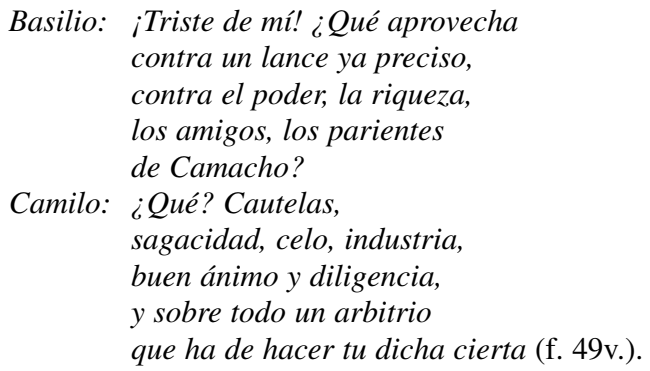

Ahora es cuando se nota que Don Quijote ha caducado. En las comedias ya no vale el desdén aristocrático ante la riqueza, como lo expresaba el caballero en Gómez Labrador o en Meléndez, I,4:

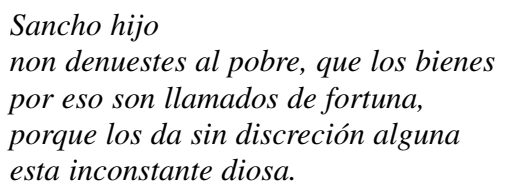

Lo que cuenta en el Siglo de las Luces es industria. Debe decirlo Sancho ante las peroratas de su amo:

\author{
pudiera Basilio \\ los versos dejando a un lado, \\ y esos entretenimientos \\ de mozalbete lozanos, \\ hacerse hombre de provecho (Gómez Labrador, f. 15).
}

Es el final de la edad de la inocencia, que ya sólo seguirá viviendo Don Quijote.

Se pueden sacar por tanto algunas conclusiones: las cuatro comedias de las Bodas de Camacho son cuatro etapas distintas en el desarrollo de una inter- 
pretación nueva del amor y los vínculos matrimoniales. De la ambientación idealizada del mundo caballeresco/pastoral no ha quedado nada más allá del cascarón de una aldea y sus rústicas costumbres, porque los problemas que debaten los personajes son los típicos de las comedias burguesas. Quiteria Basilio Camacho y el padre de la chica podrían encontrar perfectamente acomodo en cualquier obra de Molière o de Goldoni: hija de familia, enamorado pobre, padre insensible y pretendiente -aquí está la única diferencia-rico, pero no ridículo. La acción llega a buen puerto no gracias a un Arlecchino o a una serva scaltra, pero sí por la maña de un amigo ocurrente. Incluso en esto hay paralelismo entre el enredo burgués dieciochesco y las Bodas de Camacho, en que el nudo se desata mediante la intervención de un tercero, no de los interesados mismos. Los amantes sienten, pero otros se encargan del trabajo sucio.

Siguiendo en la línea de mentalidad burguesa, se mantienen dos niveles sociales: por un lado el de los amos y por otro el de los criados y para distinguirlos el tono se hace distinto. Así se encuadra la reacción de Sancho ante las ollas de Egipto de la ceremonia nupcial. Dejando de lado su evidente comicidad, la figura del escudero glotón, igual que las disparatadas bodas de Antona y Perico, sirven a marcar estéticamente el ambiente de los socialmente inferiores.

Las cuatro comedias transforman profundamente la aventura rústica en las peripecias burguesas de unos amantes contrariados y una reflexión sobre la fuerza del amor, que tal vez se encontraba también en Cervantes, aunque ciertamente no en los mismos términos. Especialmente elocuente es la Zarzuela, donde la meditación sobre el peso de la riqueza y la fortuna amorosa se sostiene en varios planos; los villanos cantan al rico Camacho porque los pobres no merecen que se los ame. En I,4, Quiteria se queja de la autoridad de su padre que la obliga a casarse con Camacho. Rasgo único en las cuatro piezas, Narcisa y Quiteria razonan sobre las cualidades de un buen marido, la segunda sosteniendo que lo principal es la discreción y la primera ensalzando sobre todo la riqueza. El otro manuscrito de la Zarzuela tiene un texto distinto pero con el mismo sentido, tal vez más explícito en lo que se refiere a la expresión de los sentimientos de Narcisa. La Zarzuela sigue con la declaración de Quiteria de que antes que casarse con Camacho se quitaría la vida, postulado bien exaltado, pero Narcisa se ríe de ella y le canta una cancioncita de que sin dinero no hay amor. Cuando en I,8, el padre da la culpa de todo a la hija por animar los ímpetus de Basilio y le manda, una vez más, que se case con Camacho, el centro de la atención se desplaza al problema de la obediencia de los hijos para con los padres en asuntos de tomar estado, pero el mensaje es ambiguo a causa del modo en que el autor trata el tema. De hecho precisamente entonces aparece D. Quijote dispuesto a defender a la muchacha de las pretensiones del padre; al ver que Leandro le contesta con malas razones estalla de ira:

Follón, malandrín, villano,

¿así tratas la persona

de un andante caballero

$y$ respondes de esa forma? 
Con estas destempladas razones se vuelve ridícula la acción del caballero y se desnaturaliza su alcance ideológico, pero no es menos cierto que la autoridad paterna queda malparada. Es importante notar que la ambigüedad final del mensaje de fondo de las cuatro comedias consiste en la contradicción entre los planteamientos del amor exaltado y el tratamiento burgués del asunto matrimonial. De una parte los esfuerzos por hacer ciertos los transportes del corazón y por el otro la acción que se queda en una burla hecha al padre y al prometido.

\title{
Resumen
}

El estudio de las cuatro versiones del episodio de las bodas de Camacho pone ante todo de manifiesto cómo se presentaba, en el siglo XVIII, la figura de Don Quijote, reducida a la de un mero personaje humorístico. Desde el punto de vista del metatexto, la teatralización del episodio desvela la formación de una sensibilidad naciente en lo referente a la autonomía amorosa de los jóvenes en relación con la autoridad de los padres. Se empieza a notar el nuevo planteamiento del matrimonio, separado del interés y fundado en el amor, lo que indica un sentimiento precursor de la mentalidad romántica.

Palabras clave: Comedia pastoril, Comedia sentimental, Ilustración, Matrimonio, Amor.

\begin{abstract}
The analysis of the four versions of the episode of Las bodas de Camacho shows, above all, how the figure of Don Quixote ws represented in the Eighteenth century as a mere humorous character. From a metatextual point of view, the dramatization of the episode discloses the growing of a new sensibility related to the independence of affections of the youth when confronted to parental authority. A new conception of marriage started to let its voice be heard, which rejected interest and was founded on love as to indicate an antecedent for the romantic mentality.
\end{abstract}

Key words: Pastoral Comedy, Sentimental Comedy, Enlightenment, Marriage, Love. 